\title{
Influence of Carvacrol on the Growth Performance, Hematological, Non-Specific Immune and Serum Biochemistry Parameters in Rainbow Trout (Oncorhynchus mykiss)
}

\author{
Ebru Yilmaz', Sebahattin Ergün², Sevdan Yilmaz² \\ ${ }^{1}$ Aquaculture and Fisheries Engineering Department, Faculty of Agriculture, Adnan Menderes University, \\ Aydın, Turkey \\ ${ }^{2}$ Department of Aquaculture, Faculty of Marine Sciences and Technology, Çanakkale Onsekiz Mart University, \\ Çanakkale, Turkey \\ Email: doktor ebru@hotmail.com
}

Received 2 March 2015; accepted 5 April 2015; published 9 April 2015

Copyright (C) 2015 by authors and Scientific Research Publishing Inc.

This work is licensed under the Creative Commons Attribution International License (CC BY). http://creativecommons.org/licenses/by/4.0/

c) (7) Open Access

\section{Abstract}

The present study investigated the effects of phytoadditive carvacrol on growth performance, feed utilization, hematological, non-specific immune and serum biochemical parameters in rainbow trout (Oncorhynchus mykiss). In trial, 240 rainbow trout which had average weight of $10.79 \pm 0.57$ was used. Fish were divided into four groups before being fed for 60 days with 0,1 (C1), 3 (C3) or 5 (C5) $\mathrm{g} / \mathrm{kg}$ of carvacrol. There were no particular differences in the growth performance, feed utilization, whole body composition, hematological parameters between the experimental group and the control group. However, as compared to control group, a significant increase of serum lysozyme activity was seen in groups receiving feed containing C3 and C5 groups after 30 days. The myeloperoxidase activity in groups (C1 and C3) was significantly higher on the 30th day of sampling. Myeloperoxidase activity of $C 5$ treated group was significantly higher on the 60th day in comparison with the control group. Serum glucose levels significantly decreased on 60th day for C1, C3 and C5 treated groups. The serum total protein, globulin and triglyceride levels of C3 treated groups was significantly higher on the 60th day in comparison with the control and other carvacrol treated groups. The level of serum cholesterol in C5 treated groups was significantly lower on the 30th day in comparison with the control and other carvacrol treated groups. The results of the present study indicated that dietary supplementation of $3 \mathrm{~g} / \mathrm{kg}$ of carvacrol in commercial diets could improve some non-specific and biochemical status in rainbow trout. 
Keywords

Carvacrol, Growth Performance, Oncorhynchus mykiss, Blood Parameters

\section{Introduction}

Aquaculture industry has shown a rapid growth in recent years. The main aims of industry area is both increasing growth rates of fish and protecting their health. Antibiotics have been used for promoting growth and struggling with illness for a long time. However, use of antibiotics in fish aquaculture have been limited and prohibited in many countries [1]. That's why; researchers have been looking for alternatives to antibiotics and the other synthetic chemicals.

Especially herbs or essential oils of herbs can be used for struggling against pathogen bacterias with its antimicrobial and antioxidant features. The features of herbals can be related to terpenoid and phenolic compounds [2]. It was seen that herbal sources can promote growth in fish, develop fish health and rise the resistance to illness as a result of their addition to fish-feed [3] [4].

Carvacrol is a major component of oregano and thyme essential oils. It is recognized as a safe component by the U.S. Food and Drug Administration (2010), by the Council of Europe (2000), and FAO/WHO Committee on Food Additives (2001). Some studies have reported that oral administration of combination of carvacrol and thymol in Ictalurus punctatus [5] and O. mykiss [6] improved growth performance, disease resistance and/or immunity. Channel catfish fed with carvacrol-based diet, significantly enhanced growth, dismutase and catalase antioxidant activity in plasma, as well as fish resistance to a challenge with Aeromonas hydrophila [5]. When a 0.025\% carvacrol-based diet was fed to Dicentrarchus labrax for 9 weeks, it decreased the mortality of fish challenged with Listonella anguillarum [7]. Dietary carvacrol supplementation at doses of $200 \mathrm{ppm}$ decreased the mortality of Oreochromis niloticus challenged with Edwardsiella tarda [8]. Since, only one study demonstrated that carvacrol $(12 \mathrm{~g} / \mathrm{kg})$ had a positive effect on trout growth performance with apparent effects towards antioxidant defence and innate immunity status [9]. However, only one dosage was used by Giannenas et al. [9]. Positive effects of carvacol treatment may be obtained provided that a different carvacrol doses can be determined and applied. Therefore, the aim of the present study was to determine dietary phytoadditive carvacrol $(1,3$, or 5 $\mathrm{g} / \mathrm{kg}$ ) can influence growth performance, proximate composition, and some hematological, non-specific immune or serum biochemical parameters in rainbow trout.

\section{Material and Methods}

\subsection{Fish and Experimental Protocol}

Trial was applied in commercial trout farm (Çobanlar) in Fethiye. In trial, 12 polyester tanks $(3 \times 0.8 \times 0.4 \mathrm{~m})$ consisted of 480 liter were used. Trial was carried out in continuous flow system and water was exchanged daily 6 - 8 times. In trial, 240 rainbow trout (O. mykiss) which has average weight of $\pm \mathrm{SD}=10.79 \pm 0.57$ was used. Fish were fed by hand 2 times a day in the ratio of $\% 2$ of their body weight during 60 days trial. Water temperature, dissolved oxygen, $\mathrm{pH}$ and EC (electrical conductivity) were measured at $7^{\circ} \mathrm{C}, 5.72 \mathrm{mg} \cdot \mathrm{L}^{-1}, 8.04,1408$ $\mu \mathrm{mhos} / \mathrm{cm}$.

\subsection{Diet Preparation}

Carvacrol (W224502, Sigma-Aldrich, Munich, Germany) was added to a commercial trout extruder feed (Çamlı Feed Company, Turkey, Table 1) at a dose of 0 (Control), 1 (C1), 3 (C3), 5 (C5) g/kg by mixer. Briefly, after heating $\left(40^{\circ} \mathrm{C}\right)$ for $3 \mathrm{~h}$ the diet was top-dressed with fish oil containing the carvacrol by slowly mixing in a food mixer. No herbal oil supplementation was made to control feed. Feeds were offered to fish two times a day as ad libitum for 60 days.

\subsection{Growth Performance and Proximate Analyses}

Growth performance of rainbow trout with different diets was considered by calculating weight gain (WG), specific growth rate (SGR), feed conversion rate (FCR) and death rate. 
Table 1. Fish diet (pellet size: $2 \mathrm{~mm}$ ).

\begin{tabular}{|c|c|}
\hline \multicolumn{2}{|l|}{ Chemical Analyses } \\
\hline Crude Protein (\%) & 49 \\
\hline Crude Lipid (\%) & 19 \\
\hline Crude Cellulose (\%) & 3 \\
\hline Crude Ash (\%) & 13 \\
\hline Energy (kcal/kg) & 4329 \\
\hline \multicolumn{2}{|l|}{ Amino Acids (\%) } \\
\hline Lysine & 4.7 \\
\hline Methionine + Cystine & 2.4 \\
\hline \multicolumn{2}{|l|}{ Vitamins (per kg Feed) } \\
\hline A (IU) & 2500 \\
\hline D3 (IU) & 3050 \\
\hline E (mg) & 240 \\
\hline $\mathrm{K}$ (mg) & 10 \\
\hline C (mg) & 250 \\
\hline \multicolumn{2}{|l|}{ Macro Elements (\%) } \\
\hline Calcium & $1-2$ \\
\hline Total Phosphor & 1.5 \\
\hline Sodium & $0.2 / 1$ \\
\hline
\end{tabular}

Ingredients: fish meal, fish oil, soybean and by products, wheat and by products, yeast and by products, amino acids, vitamins and minerals.

$$
\begin{gathered}
\text { WG }(\mathrm{g})=\text { final weight }(\mathrm{FW})(\mathrm{g})-\text { initial weight }(\mathrm{IW})(\mathrm{g}) \\
\operatorname{SGR}(\% / d)=[(\ln \text { final weight }(\mathrm{g})-\ln \text { initial weight }(\mathrm{g})) / \text { days }] \times 100 \\
\text { FCR }=\text { feed intake }(\mathrm{g}) / \text { weight gain }(\mathrm{g})
\end{gathered}
$$

Proximate analyses of the diets were performed using standard methods [10]. Moisture was detected after drying at $105^{\circ} \mathrm{C}$ until a constant weight was achieved. Crude protein was analyzed by the Kjeldahl method, and crude ash by incineration at $525^{\circ} \mathrm{C}$ in a muffle furnace for $12 \mathrm{~h}$. Crude fat was analyzed by methanol/chloroform extraction [11].

\subsection{Blood Collection}

Blood samples of six fish/groups were collected randomly from the caudal vein using a vacutainer fitted $5 \mathrm{~mL}$ on days 30 and 60. For blood sampling, fish were anaesthetized with MS222 (Sigma Aldrich, Steinheim, Germany) [12]. They were well wiped and cleaned in order to avoid mucus mixing into the blood, and blood was taken from the fish through the caudal vein by a 2.5-mL plastic syringe without harming the fish [13] Then, 200 $\mu \mathrm{L}$ of blood was transferred to ethylenediaminetetraacetic acid (EDTA) tubes (BD, Oxford, UK) for hematological analysis. The other $600 \mu \mathrm{L}$ of blood was harvested in plastic biochemistry tubes (Vacutest Kima s.r.l., Piove di Sacco, Italy). After the blood was coagulated, the tubes were centrifuged at $4000 \times \mathrm{g}$ for $10 \mathrm{~min}$ for serum separation, which was stored below $-20^{\circ} \mathrm{C}[14]$.

\subsection{Hematological Analysis}

Red blood cells (RBC, $10^{6} \mathrm{~mm}^{3}$ ), hematocrit (Hct, \%) and hemoglobin (Hb, g/dL) were determined by using the 
method by Blaxhall and Daisley [15]. RBC was counted with a Thoma hemocytometer using Dacie’s diluting fluid. Hct was determined using a capillary hematocrit tube. Hb concentration was determined by spectrophotometry $(540 \mathrm{~nm})$ using the cyanomethahaemoglobin method. The hematological indices of mean cell haemoglobin concentration (MCHC: $\mathrm{g} \cdot \mathrm{dL}^{-1}$ ), meancell haemoglobin (MCH: pg) and meancell volume (MCV: $\mathrm{fL}$ ) were calculated using the total RBC count, $\mathrm{Hb}$ concentration and $\mathrm{Ht}$ [16]. Mean corpuscular volume (MCV), mean corpuscular hemoglobin (MCH), and mean corpuscular hemoglobin concentration (MCHC) were calculated using the following formula [17].

$$
\begin{aligned}
& \operatorname{MCV}\left(\mu \mathrm{m}^{3}\right)=[(H c t, \%) \times 10] /\left(R B C, \times 10^{6} \text { per } \mathrm{mm}^{3}\right), \\
& M C H(\mathrm{pg})=[(H b, g / d L) \times 10] /\left(R B C, \times 10^{6} \text { per } \mathrm{mm}^{3}\right),
\end{aligned}
$$

and

$$
\operatorname{MCHC}(\%)=[(H b, g / d L) \times 100] /(H c t, \%)
$$

\subsection{Immunological Analysis}

\subsubsection{Myeloperoxidase Activity}

Total myeloperoxidase (MPO) content was measured according to Quade and Roth [18] with slight modification. A volume of $10 \mu \mathrm{l}$ serum was diluted with $90 \mu$ l of Hank's balanced salt solution without $\mathrm{Ca}^{2}$ or $\mathrm{Mg}^{2}$ in 96 well plate. Then, $35 \mu \mathrm{l}$ of $0.1 \mathrm{mg} / \mathrm{mL}$ (w/v) 3,3',5,5'-tetramethylbenzidine dihydrochloride (TMB, Sigma-Aldrich, Munich, Germany) and $0.006 \%$ fresh hydrogen peroxide were added. The reaction was followed kinetically by measuring the increase of absorbance. Reaction velocities were determined as International Units, defined as the amount of enzyme required to produce an increase in absorbance of $0.001 / \mathrm{min}$ in $0.5 \mathrm{~mL}$ reaction mixture $(\Delta \mathrm{A}$ $450 / \mathrm{min} / \mathrm{ml})$.

\subsubsection{Lysozyme Activity}

Serum lysozyme was assessed using the turbidometric assay [19]. The same amount of PBS was added onto the $100 \mu \mathrm{l}$ serum sample. Then, $800 \mu \mathrm{l}$ of Micrococcus lysodeikticus (Sigma, ATCC 4698) suspension at $0.2 \mathrm{mg} / \mathrm{mL}$ in PBS was added, and at the minutes 0.5 and 4.5, readings were taken from the spectrophotometer at $530 \mathrm{~nm}$. The mixture was incubated at RT, and its OD was measured after 0.5 and $4.5 \mathrm{~min}$ at $530 \mathrm{~nm}$ using a spectrophotometer. One unit of lysozyme activity was defined as the amount of enzyme producing a decrease in absorbance of 0.001/min.

\subsubsection{Serum Biochemical Analyses}

Biochemical indices in serum including glucose (GLU), total protein (TPROT), albumin (ALB), triglyceride (TRI), cholesterol (CHOL) globulin (GLO) were determined using bioanalytic test kits (Bioanalytic Diagnostic Industry, Co) and measured by a spectrophotometer (PG Instruments, UK). Serum globulin was determined by the following formula; globulin $=$ total protein - albumin .

\subsubsection{Statistic}

In this study, the variation analyses were carried out with Duncan multiple comparison tests, and the differences between groups were carried out via the use of SPSS 17 statistics program in order to evaluate the relationships between the data of blood, proximate composition and growth parameters obtained from the test group.

\section{Results and Discussion}

Growth results are presented in Table 2. No particular difference was found in the final weight gain, FCR and SGR $(P>0.05)$. In parallel, no significant difference was found between rainbow trout (IW: $111.8 \mathrm{~g})$ fed with the carvacrol supplement at $12 \mathrm{~g} / \mathrm{kg}$ and the control diet in terms of weight gain, although the carvacrol group had lower FCR than the control group [9]. Zheng et al. [5] reported that carvacrol (0.05\%) significantly improved weight gain and FCR in rainbow trout (IW: $50 \mathrm{~g}$ ). These results indicate that the action modes of different levels of carvacrol in small fish and big fish are different and this may result from physiological differences in different stages of the fish life cycle. 
Table 2. Growth performance, feed utilization, and survival in rainbow trout that were fed diets containing different levels of carvacrol $(0,1,3$, or $5 \mathrm{~g} / \mathrm{kg}$ of feed; diets Control, C1, C3, and C5, respectively) for 60 day.

\begin{tabular}{|c|c|c|c|c|}
\hline & Control & $\mathrm{C} 1$ & C3 & C5 \\
\hline IW (g) & $11.32 \pm 0.27^{\mathrm{a}}$ & $11.07 \pm 0.54^{\mathrm{a}}$ & $10.67 \pm 0.16^{\mathrm{a}}$ & $10.75 \pm 0.29^{a}$ \\
\hline FW (g) & $27.40 \pm 0.57^{\mathrm{a}}$ & $26.49 \pm 0.21^{\mathrm{a}}$ & $26.71 \pm 0.67^{\mathrm{a}}$ & $28.27 \pm 0.35^{\mathrm{a}}$ \\
\hline WG (g) & $16.09 \pm 0.78^{\mathrm{a}}$ & $15.41 \pm 0.64^{\mathrm{a}}$ & $16.04 \pm 0.63^{\mathrm{a}}$ & $17.52 \pm 0.49^{\mathrm{a}}$ \\
\hline FCR & $0.97 \pm 0.05^{\mathrm{a}}$ & $1.01 \pm 0.13^{\mathrm{a}}$ & $1.06 \pm 0.05^{\mathrm{a}}$ & $0.95 \pm 0.05^{\mathrm{a}}$ \\
\hline SGR (\%/d) & $1.47 \pm 0.07^{\mathrm{a}}$ & $1.45 \pm 0.09^{\mathrm{a}}$ & $1.53 \pm 0.04^{\mathrm{a}}$ & $1.61 \pm 0.05^{\mathrm{a}}$ \\
\hline
\end{tabular}

Values are mean \pm SE $(n=6)$. Within a row, means with differing letters are significantly different $(P<0.05)$.

The whole-body proximate compositions of fish at the end of the experiment are presented in Table 3. There was no significant difference related to protein, lipid, ash and moisture between the experimental group and the control group. Similarly, there was no significant difference in proximate composition of rainbow trout fed with the carvacrol supplement at $0.05 \%$ in comparison with the control group [5].

It is often suggested that hematological parameters are useful stress or disease indicators for fish; and the changes in RBC count, Hct value, Hb value and erythrocyte indexes are important to detect organ health status [4] [20] [21]. The effects of carvacrol on rainbow trout hematological variables are presented in Table 4. The RBC count, $\mathrm{Hb}$ concentration, $\mathrm{Hct}, \mathrm{MCV}, \mathrm{MCH}$, and MCHC in the treatment groups did not vary significantly from the values observed for the control group. In the published literature, no previous report written on dietary carvacrol's effects on the hematological parameters of fish was found. However, one study has reported that the combination of carvacrol and thymol additives $(1,2$, or $3 \mathrm{~g} / \mathrm{kg}$ ) did not change hematological parameters (Hct, Hb concentration, RBC, MCV, MCH or MCHC) in rainbow trout [6].

Myeloperoxidase is contained in the polymorphonuclear neutrophils, monocytes, and macrophages [22]. It is known to participate to microbicidal activity and its activity gives clues about fish neutrophil ability to kill microorganisms [23]. An exceptionally widespread defence molecule lysozyme is important for protection against fish pathogen as it directly activates the polymorphonuclear leukocytes and macrophages or it promotes phagocytosis as an opsonin of freshwater and marine fish [24]. The myeloperoxidase activity in groups (C1 and C3) was significantly higher $(P<0.05)$ on the 30th day of sampling (Figure 1 ). Myeloperoxidase activity of C5 treated group was significantly $(P<0.05)$ higher on the 60th day in comparison with the control group. As compared to control group, a significant increase $(P<0.05)$ of serum lysozyme activity was observed in groups with the feed containing C3 and C5 groups after 30 days (Figure 2). However, lysozyme levels of carvacrol treated groups were not significantly $(P>0.05)$ different on the 60th day. Similarly, there was no significant difference in lysozyme levels of rainbow trout fed with the carvacrol supplement at $0.05 \%$ when compared to control group after 8 weeks [5]. Volpatti et al. [7] reported that when fish fed with $0.025 \%$ carvacrol for 1 to 4 week exhibited a similar trend in the level of lysozyme, but this parameter was significantly lower when compared with the control after 8 weeks. Feeding the diet which contains $0.05 \%$ carvacrol compared with the control diet resulted in a significant decrease of the lysozyme after 4 weeks, although the lysozyme didn't significantly change after 8 weeks.

In the present study and other similar studies showed that non-specific immune responses exhibited significant enhancement in their activity in different time of feeding with the carvacrol diet and didn't show any modulation of the immune parameters on all sampling days. It is known that the fish innate immune system lacks memory, the duration of its response is always shorter than the specific system [25]. So, each activity shows peaks that disappear in time and that may not coincide with magnitude or time together with the peaks of other activities [26] [27].

Serum glucose has often been suggested as a useful nonspecific stress indicator [28]. The present study showed that the GLU levels (Table 5) significantly decreased on 60th day for C1, C3 and C5 treated groups when compared to control groups $(P<0.05)$. The decreased glucose levels might be associated with hypoglycemic effects of carvacrol [29].

The increase of serum protein, albumin and globulin levels indicates the increase in innate immune response of fish [4] [30]. The level of TPROT and GLO in treatment groups was insignificant on 30th day of sampling. However, TPROT and GLO levels of C3 treated groups were significantly $(P<0.05)$ higher on the 60th day in 


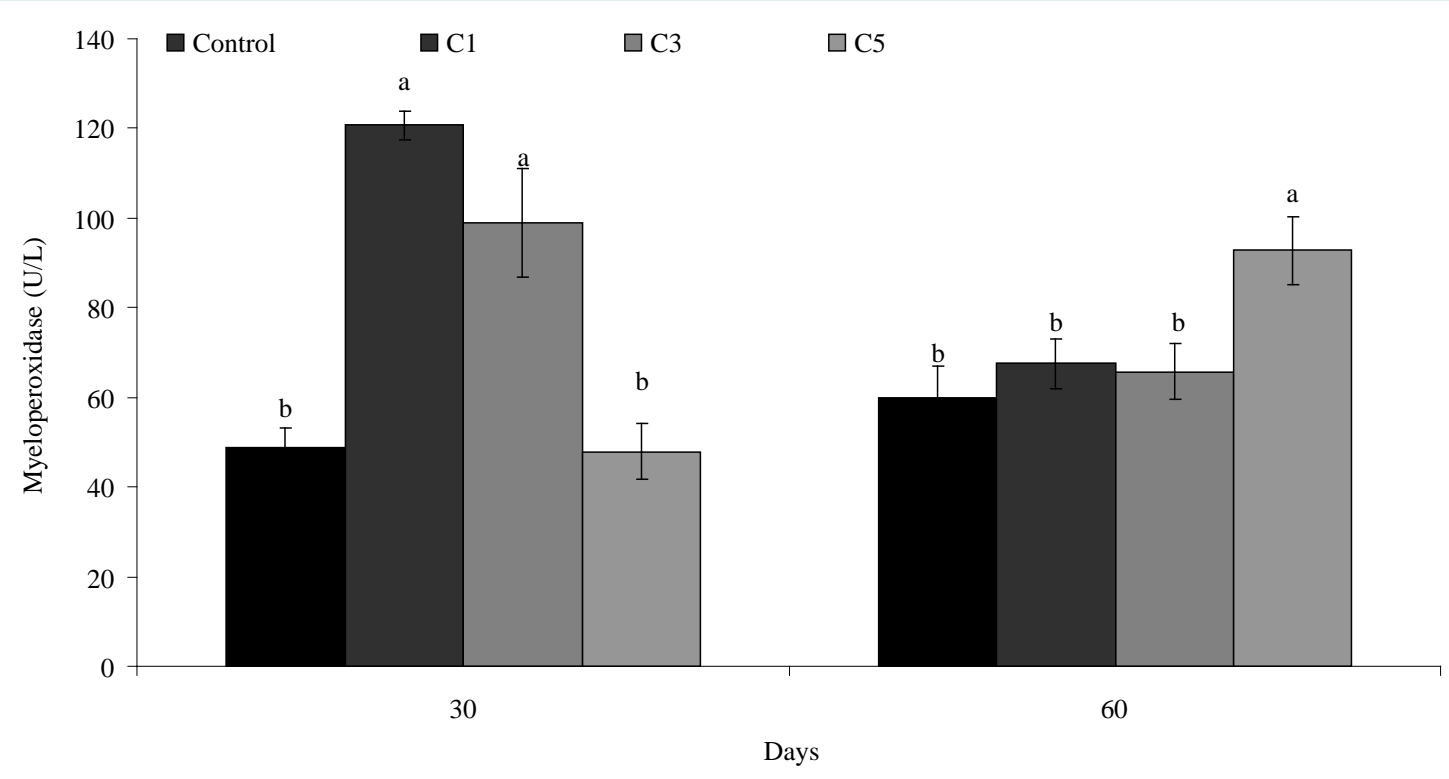

Figure 1. Changes of myeloperoxidase activity in rainbow trout fed with carvacrol diets as compared to control diet on days 30 and 60 . Data represent the mean \pm SE. Data in the same row with different superscript are significantly different $(P<0.05)$. (See Table 2 for definition of treatment codes).

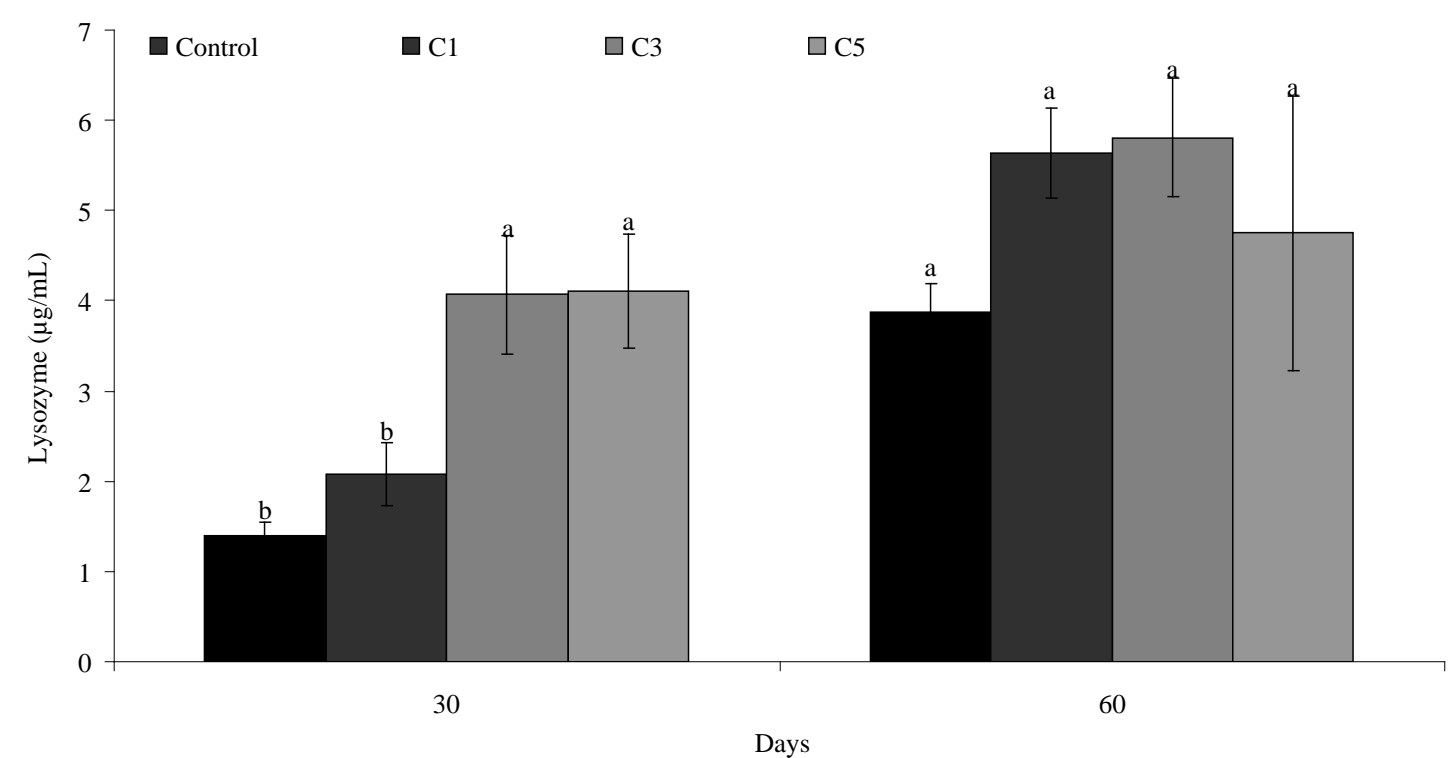

Figure 2. Changes of lysozyme activity in rainbow trout fed with carvacrol diets as compared to control diet on days 30 and 60 . Data represent the mean \pm SE. Data in the same row with different superscript are significantly different $(P<0.05)$. (See Table 2 for definition of treatment codes).

Table 3. Whole-body proximate composition (\%) of rainbow trout fed diets with different levels of carvacrol for 60 day.

\begin{tabular}{ccccc}
\hline Composition (\%) & Control & C1 & C3 & C5 \\
\hline Protein & $17.81 \pm 0.58^{\mathrm{a}}$ & $18.02 \pm 0.47^{\mathrm{a}}$ & $16.51 \pm 0.58^{\mathrm{a}}$ & $16.78 \pm 0.62^{\mathrm{a}}$ \\
Lipid & $6.28 \pm 0.80^{\mathrm{a}}$ & $5.56 \pm 0.29^{\mathrm{a}}$ & $6.66 \pm 0.61^{\mathrm{a}}$ & $6.07 \pm 0.18^{\mathrm{a}}$ \\
Ash & $2.72 \pm 0.10^{\mathrm{a}}$ & $2.58 \pm 0.08^{\mathrm{a}}$ & $2.60 \pm 0.02^{\mathrm{a}}$ & $2.51 \pm 0.04^{\mathrm{a}}$ \\
Moisture & $72.94 \pm 1.30^{\mathrm{a}}$ & $73.10 \pm 0.03^{\mathrm{a}}$ & $73.22 \pm 0.41^{\mathrm{a}}$ & $73.22 \pm 0.15^{\mathrm{a}}$ \\
\hline
\end{tabular}

Values are mean $\pm \mathrm{SE}(\mathrm{n}=6)$. Within a row, means with differing letters are significantly different $(P<0.05)$. (See Table 2 for definition of treatment codes). 
Table 4. Hematological parameters in rainbow trout that were fed diets containing different levels of carvacrol for 60 day.

\begin{tabular}{ccccc}
\hline Blood Parameter & Control & C1 & C3 & C5 \\
\hline Hb $\left(\mathrm{g} \cdot \mathrm{dL}^{-1}\right)$ & $5.07 \pm 0.15^{\mathrm{a}}$ & $5.26 \pm 0.18^{\mathrm{a}}$ & $4.87 \pm 0.16^{\mathrm{a}}$ & $5.00 \pm 0.37^{\mathrm{a}}$ \\
Hct (\%) & $35.60 \pm 0.42^{\mathrm{a}}$ & $37.80 \pm 0.30^{\mathrm{a}}$ & $37.00 \pm 0.58^{\mathrm{a}}$ & $36.60 \pm 0.67^{\mathrm{a}}$ \\
RBC $\left(10^{6} \mathrm{~mm}^{3}\right)$ & $3.55 \pm 0.06^{\mathrm{a}}$ & $3.78 \pm 0.06^{\mathrm{a}}$ & $3.70 \pm 0.07^{\mathrm{a}}$ & $3.65 \pm 0.09^{\mathrm{a}}$ \\
MCV (fL) & $100.42 \pm 0.43^{\mathrm{a}}$ & $100.14 \pm 0.56^{\mathrm{a}}$ & $100.03 \pm 0.49^{\mathrm{a}}$ & $100.21 \pm 1.00^{\mathrm{a}}$ \\
MCH (pg) & $14.31 \pm 0.50^{\mathrm{a}}$ & $13.93 \pm 0.44^{\mathrm{a}}$ & $13.19 \pm 0.49^{\mathrm{a}}$ & $13.66 \pm 0.96^{\mathrm{a}}$ \\
MCHC (g. $\left.\mathrm{dL}^{-1}\right)$ & $14.25 \pm 0.48^{\mathrm{a}}$ & $13.92 \pm 0.45^{\mathrm{a}}$ & $13.18 \pm 0.46^{\mathrm{a}}$ & $13.67 \pm 1.02^{\mathrm{a}}$ \\
\hline
\end{tabular}

Hb, haemoglobin; Hct, hematocrit; RBC, red blood cells; MCV, mean cell volume; MCH, mean cell haemoglobin; MCHC, mean cell haemoglobin concentration. Data represent as mean \pm SE. Within a row, means with differing letters are significantly different $(P<0.05)$. (See Table 2 for definition of treatment codes).

Table 5. Changes of serum biochemical parameters in rainbow trout fed withcarvacroldiets as comparedtocontroldiet on days 30 and 60 .

\begin{tabular}{cccccc}
\hline & Days & Control & C1 & C3 & C5 \\
\hline GLU (mg/dL) & 30 & $119.26 \pm 5.28^{\mathrm{a}}$ & $141.12 \pm 8.67^{\mathrm{a}}$ & $139.42 \pm 17.52^{\mathrm{a}}$ & $136.93 \pm 11.06^{\mathrm{a}}$ \\
& 60 & $116.83 \pm 6.63^{\mathrm{a}}$ & $63.18 \pm 4.16^{\mathrm{b}}$ & $59.90 \pm 5.28^{\mathrm{b}}$ & $54.88 \pm 8.63^{\mathrm{b}}$ \\
TPROT (g/dL) & 30 & $8.72 \pm 0.87^{\mathrm{a}}$ & $10.63 \pm 1.07^{\mathrm{a}}$ & $10.21 \pm 0.39^{\mathrm{a}}$ & $10.02 \pm 0.87^{\mathrm{a}}$ \\
& 60 & $7.89 \pm 0.34^{\mathrm{bc}}$ & $9.27 \pm 0.52^{\mathrm{b}}$ & $11.25 \pm 0.61^{\mathrm{a}}$ & $7.40 \pm 0.53^{\mathrm{c}}$ \\
ALB (g/dL) & 30 & $3.06 \pm 0.31^{\mathrm{a}}$ & $2.93 \pm 0.29^{\mathrm{a}}$ & $3.07 \pm 0.34^{\mathrm{a}}$ & $3.58 \pm 0.54^{\mathrm{a}}$ \\
& 60 & $2.43 \pm 0.06^{\mathrm{a}}$ & $2.57 \pm 0.11^{\mathrm{a}}$ & $2.22 \pm 0.04^{\mathrm{a}}$ & $2.39 \pm 0.16^{\mathrm{a}}$ \\
GLO (g/dL) & 30 & $5.65 \pm 0.91^{\mathrm{a}}$ & $7.71 \pm 1.01^{\mathrm{a}}$ & $7.14 \pm 0.38^{\mathrm{a}}$ & $6.44 \pm 0.87^{\mathrm{a}}$ \\
& 60 & $5.47 \pm 0.36^{\mathrm{bc}}$ & $6.70 \pm 0.47^{\mathrm{b}}$ & $9.03 \pm 0.59^{\mathrm{a}}$ & $5.01 \pm 0.56^{\mathrm{c}}$ \\
TRI (mg/dL) & 30 & $124.11 \pm 12.64^{\mathrm{a}}$ & $130.85 \pm 12.29^{\mathrm{a}}$ & $121.81 \pm 13.40^{\mathrm{a}}$ & $112.32 \pm 17.01^{\mathrm{a}}$ \\
& 60 & $161.91 \pm 12.76^{\mathrm{b}}$ & $151.28 \pm 12.21^{\mathrm{b}}$ & $215.96 \pm 17.76^{\mathrm{a}}$ & $154.89 \pm 8.35^{\mathrm{b}}$ \\
\hline & 30 & $253.07 \pm 12.31^{\mathrm{a}}$ & $260.33 \pm 10.21^{\mathrm{a}}$ & $253.33 \pm 11.02^{\mathrm{a}}$ & $153.53 \pm 15.76^{\mathrm{b}}$ \\
\hline
\end{tabular}

Values are mean $\pm \mathrm{SE}(\mathrm{n}=6)$. Within a row, means with differing letters are significantly different $(P<0.05)$. (See Table 2 for definition of treatment codes).

comparison with the control, C1 and C5 treated groups. In addition, serum ALB levels were similar in all treatment groups.

Major blood lipid components, such as triglycerides, phospholipids, and cholesterol are affected by diet and stress levels in fish [31]. The level of TRI in treatment groups was insignificant on 30th day of sampling $(P>0.05)$. However, TRI levels of C3 treated groups were significantly $(P<0.05)$ higher on the 60th day in comparison with the control, C1 and C5 treated groups. Carvacrol can enhance dietary lipid emulsification and transportation of absorbed lipids into the serum. Although more detailed studies are required for a more clear understanding. Because, the level of CHOL in C5 treated groups was significantly $(P<0.05)$ lower on the 30th day in comparison with the control and other carvacrol treated groups. Furthermore, the level of CHOL in treatment groups was insignificant on 60th day of sampling $(P>0.05)$.

\section{Conclusion}

In conclusion, the results of the present study indicate that dietary supplementation of $3 \mathrm{~g} / \mathrm{kg}$ of carvacrol in commercial diets could improve some non-specific immune and biochemical status in rainbow trout, without 
adversely affecting hematological parameters, growth performance or feed utilization. Thus, carvacrol can be utilized as health promoter in fish culture. Further investigation on the potential effects of carvacrol on control of trout diseases is encouraged.

\section{Acknowledgements}

We would like to thank the Çanakkale Onsekiz Mart University Research Fund for financial assistance (the project number COMU BAP FDK-2013-102) and Adnan ÇOBAN for providing research facilities.

\section{References}

[1] Citarasu, T. (2010) Herbal Biomedicines: A New Opportunity for Aquaculture İndustry. Aquaculture International, 18, 403-414. http://dx.doi.org/10.1007/s10499-009-9253-7

[2] Conner, D.E. (1993) Naturally Occurring Compounds. In: Davidson, P. and Branen, A.L., Eds., Antimicrobials in Foods, Marcel Dekker, Inc., New York, 441-468.

[3] Chakrabort, S.B. and Hancz, C. (2011) Application of Phytochemicals as İmmunostimulant, Antipathogenic and Antistress Agents in Finfish Culture. Reviews in Aquaculture, 3, 103-119.

[4] Yılmaz, S., Ergün, S. and Çelik, E.Ş. (2014) Effect of Dietary Spice Supplementations on Welfare Status of Sea Bass, Dicentrarchus labrax L. Proceedings of the National Academy of Sciences, Biological Sciences, India, 1-9. http://dx.doi.org/10.1007/s40011-014-044-2

[5] Zheng, Z.L., Tan, J.Y.W., Liu, H.Y., Zhou, X.H., Xiang, X. and Wang, K.Y. (2009) Evaluation of Oregano Essential Oil (Origanum heracleoticum L.) on Growth, Antioxidant Effect and Resistance against Aeromonas hydrophila in Channel Catfish (Ictalurus punctatus). Aquaculture, 292, 214-218. http://dx.doi.org/10.1016/j.aquaculture.2009.04.025

[6] Ahmadifar, E., Falahatkar, B. and Akrami, R. (2011) Effects of Dietary Thymol-Carvacrol on Growth Performance, Hematological Parameters and Tissue Composition of Juvenile Rainbow Trout, Oncorhynchus mykiss. Journal of Applied Ichthyology, 27, 1057-1060. http://dx.doi.org/10.1111/j.1439-0426.2011.01763.x

[7] Volpatti, D., Chiara, B., Francesca, T. and Marco, G. (2012) Growth Parameters, Innate Immune Response and Resistance to Listonella (Vibrio) anguillarum of Dicentrarchus labrax Fed Carvacrol Supplemented Diets. Aquaculture Research, 45, 31-44. http://dx.doi.org/10.1111/j.1365-2109.2012.03202.x

[8] Rattanachaikunsopon, P. and Phumkhachorn, P. (2010) Assessment of Synergistic Efficacy of Carvacrol and Cymene against Edwardsiella tarda in Vitro and in Tilapia (Oreochromis niloticus). African Journal of Microbiology Research, 4, 420-425.

[9] Giannenas, I., Triantafillou, E., Stavrakakis, S., Margaroni, M., Mavridis, S., Steiner, T. and Karagouni, E. (2012) Assessment of Dietary Supplementation with Carvacrol or Thymol Containing Feed Additives on Performance, İntestinal Microbiota and Antioxidant Status of Rainbow Trout (Oncorhynchus mykiss). Aquaculture, 350, $26-32$. http://dx.doi.org/10.1016/j.aquaculture.2012.04.027

[10] AOAC (1998) Official Methods of Analysis. AOAC, Arlington.

[11] Folch, J., Lees, M. and Sloane-Stanley, G.H. (1957) A Simple Method for the İsolation and Purification of Total Lipides from Animal Tissues. The Journal of Biological Chemistry, 226, 497-509.

[12] Smith, C., Shaw, B., Handy, R.D. (2007) Toxicity of Single Walled Carbon Nanotubes to Rainbow Trout, (Oncorhynchus mykiss): Respiratory Toxicity, Organ Pathologies, and Other Physiological Effects. Aquatic Toxicology, 82, 94109. http://dx.doi.org/10.1016/j.aquatox.2007.02.003

[13] Val, A.L., De Menezes, G.C. and Wood, C.M. (1998) Red Blood Cell Adrenergic Responses in Amazonian Teleost. Journal of Fish Biology, 52, 83-93. http://dx.doi.org/10.1111/j.1095-8649.1998.tb01554.x

[14] Bricknell, I.R., Bowden, T.J., Bruno, D.W., MacLachlan, P., Johnstone, R. and Ellis, A.E. (1999) Susceptibility of Atlantic Halibut, Hippoglossus hippoglossus (L.) to İnfection with Typical and Atypical Aeromonas salmonicida. Aquaculture, 175, 1-13. http://dx.doi.org/10.1016/S0044-8486(99)00025-3

[15] Blaxhall, P.C. and Daisley, K.W. (1973) Routine Haematological Methods for Use with Fish Blood. Journal of Fish Biology, 5, 771-781. http://dx.doi.org/10.1111/j.1095-8649.1973.tb04510.x

[16] Lee, R.G., Foerster, J., Jukens, J., Paraskevas, F., Greer, J.P. and Rodgers, G.M. (1998) Wintrobe’s Clinical Hematology. 10th Edition, Lippincott Williams \& Wilkins, New York.

[17] Bain, B.J., Lewis, S.M. and Bates, I. (2006) Basic Haematological Techniques. In: Lewis, S.M., Bain, B.J. and Bates, I., Eds., Dacie and Lewis Practical Haematology, 10th Edition, Churchill Livingstone Elsevier, Philadelphia, 26-54. http://dx.doi.org/10.1016/B0-44-306660-4/50007-6

[18] Quade, M.J., Roth, J.A. and Rapid, A. (1997) A Rapid, Direct Assay to Measure Degranulation of Bovine Neutrophil 
Primary Granules. Veterinary Immunology and Immunopathology, 58, 239-248. http://dx.doi.org/10.1016/S0165-2427(97)00048-2

[19] Ellis, A.E. (1990) Lysozyme Assays. In: Stolen, J.S., Fletcher, T.C., Anderson, D.P., Roberson, B.S. and van Muiswinkel, W.B., Eds., SOS Publications, Fair Haven, 101-103.

[20] Campbell, T.W. (2004) Clinical Chemistry of Fish and Amphibians. In: Thrall, M.A., Baker, D.C., Campbell, T.W., DeNicola, D., Fettman, M.J., Lassen, E.D., Rebar, A. and Weiser, G., Eds., Veterinary Hematology and Clinical Chemistry, Lippincott Williams \& Wilkins, Pennsylvania, 499-517.

[21] Başusta, G.A. (2005) Fish Hematology and Hematological Techniques. In: Karatas, M., Ed., Research Techniques in Fish Biology (in Turkish), Nobel Publications, Ankara, 275-300.

[22] Klebanoff, S.J. (1992) Oxygen Metabolites from Phagocytes. In: Gallin, I.M., Goldstein, J.I. and Snyderman, M.D., Eds., Inflammation: Basic Principles and Clinical Correlates, Raven Press, New York, 391-444.

[23] Siwicki, A.K. and Anderson, D.P. (1993) Nonspecific Defence Mechanisms Assay in Fish: I. Phagocytic Index, Adherence and Phagocytic Ability of Neutrophils (NBT Test) and Myeloperoxidase Activity Test. In: Siwicki, A.K., Anderson, D.P. and Waluga, J., Disease Diagnosis and Prevention Methods, FAO-Project GCP/INT/JPA, IFI, Olsztyn, 95-104.

[24] Siwicki, A.K. and Anderson, D.P. (1993) Nonspecific Defence Mechanisms Assay in Fish: II. Potential Killing Activity of Neutrophils and Macrophages, Lysozyme Activity in Serum and Organs. In: Siwicki, A.K., Anderson, D.P. and Waluga, J., Eds., Disease Diagnosis and Prevention Methods, FAO-Project GCP/INT/526/JPN, IFI, Olsztyn, 105-111.

[25] Anderson, D.P. (1992) Immunostimulants, Adjuvants, and Vaccine Carriers in Fish: Applications to Aquaculture. Annual Review of Fish Diseases, 2, 281-307. http://dx.doi.org/10.1016/0959-8030(92)90067-8

[26] Ortuno, J., Esteban, M.A. and Meseguer, J. (1999) Effect of High Dietary İntake of Vitamin C on Nonspecific İmmune Response of Gilthead Seabream (Sparus aurata L.). Fish \& Shellfish Immunology, 9, 429-443.

[27] Christybapita, D., Divyagnaneswari, M. and Dinakaran, M.R. (2007) Oral Administration of Eclipta alba Leaf Aqueous Extract Enhances the Non-Specific Immune Responses and Disease Resistance of Oreochromis mossambicus. Fish \& Shellfish Immunology, 23, 840-852. http://dx.doi.org/10.1016/j.fsi.2007.03.010

[28] Heath, A.G. (1995) Water Pollution and Fish Physiology. CRC Lewis Publishers, London.

[29] Deng, W., Lu, H. and Teng, J. (2013) Carvacrol Attenuates Diabetes-Associated Cognitive Deficits in Rats. Journal of Molecular Neuroscience, 51, 813-819. http://dx.doi.org/10.1007/s12031-013-0069-6

[30] Wiegertjes, G.F., Stet, R.J., Parmentier, H.K. and Van Muiswinkel, W.B. (1996) Immunogenetics of Disease Resistance in Fish: A Comparative Approach. Developmental \& Comparative Immunology, 20, 365-381. http://dx.doi.org/10.1016/S0145-305X(96)00032-8

[31] McDonald, D.G. and Milligan, C.L. (1992) Chemical Properties of the Blood. In: Hoar, W.S., Randall, D.J. and Farrell, A.P., Eds., Fish Physiology, Volume 12, Part B: The Cardiovascular System, Academic Press, San Diego, 56-113. http://dx.doi.org/10.1016/S1546-5098(08)60009-6 